\title{
CONTINUITY OF ACTIVITIES DURING THE CRISIS SITUATIONS ON RAILWAY TRANSPORT BRANCH
}

\begin{abstract}
The continuity of activity field during the crisis situations is a way, how to reduce activities which is harmless for the transport. The goal is ensure minimal demanded level of services performed in the transport branch. This minimal level for performing the transport services are necessary for train operating.
\end{abstract}

Key Words: Business Continuity management, railway transport, infrastructure manager, train operating company

Dana Rozová ${ }^{1}$

${ }^{1}$ Jan Perner Transport Faculty, University of Pardubice, Studentská 95, 53210 Pardubice 2, rozovad@szdc.cz

Martin Šstr ${ }^{2}$

${ }^{2}$ Jan Perner Transport Faculty, University of Pardubice, Studentská 95, 53210 Pardubice 2, martin.sustr@upce.cz

\section{Introduction}

The railway transport is part of the complex transport system. The first role in this system represents infrastructure manager. In the transport system are important train operating companies and administrative authorities, too. The individual activities in the railway transport seem to be independent. It is not only following one another, but mutually interconnected. This interconnection also relates to the mutual co-operation of the various railway companies. The reconstruction, boosting or new construction of railway infrastructure in the Czech Republic is organized by infrastructure manager. These include particular repairs of railway lines and stations, timetabling, train path allocation and direct traffic organization. Train operating provide service related to the train running. The railway administrative authorities decide on the classification of the railroad into individual categories, carry out state supervision in the field of railways and building regulations, assess the causes of the occurrence of extraordinary events and approve the type and competence of the technicians and personal competence.

The functioning of the interconnected and coherent activities of all important processes within the railway transport is a basic feature for the safe and regular railway functioning. Every change of any act has impact in other parts. In order to achieve the necessary balance, it is necessary to use different variants of related actions. In every time activities in the railway system is like a live organism and like a live organism it must be in balance.

\section{Management of continuity of activities}

The Business Continuity Management is applicate in the railway transport for short time. It is a new branch in this field. This new branch is closely related with safety management. The Business Continuity Management is generally aimed at management of all activities in the field in order to ensure maximum functionality and maintain the highest possible performance in the current situation. It is an organization management process that is a tool to reduce the probability of interruption. This process identifies the impacts that threaten the organization and its functioning with aim to create processes and environments that reduce the risk of interruption of activities. In the case of an interruption of train operation, BCM will allow a flexible, efficient and appropriate response and ensure that key processes are restored at a predetermined minimum level and in a predetermined time (Rozová 2015).

In addition to the Business Continuity Management, the management element can be found in Safety Management, Risk Management, and Crisis Management. All relate with the risk management strategy in rail transport, but also it relate with the initial reporting and subsequent emergency response, risk analysis, emergency and crisis planning. They can be taken as four commonly linked components of a unified strategy. The difference and the relationship between them are not commonly understood. Often one concept is changed with the other three. Often, a combination of all four occurs. We can say that they are all important and each of them has a role for decision in dealing with extraordinary situations (Smejkal, Rais 2010).

Safety management in railway transport is the subject of management that solves the safety of resources in the railway companies. It deals with both physical and technological security. It includes operational safety, personal security and administrative safety, safety of information and communication systems, and also the protection of personal data. This area of management is very closely related to the risk management. Thanks to the different methods and tools, individual subjects in the railway environmental create conditions that will help to prevent or reduce identified risks.

The Business Continuity Management is add-on to the Risk management. By concentrating on the consequences of the interruption that this management carries out, it is possible to identify those products on which survival depends, and also to find out what needs to be done for the further functioning of the transport. The Business Continuity Management and the risk management can not be clearly merged or split. Both processes can complement one another.

The crisis management of the European Union and the North Atlantic Treaty Organization members has a different meaning and occupies a different area than in 
the Czech Republic. This term identifies "controlled" disputes as well as security in post-conflict areas and conflict prevention. (Valášek, Kovařík et al. 2008). The crisis management in the Czech Republic is a set of tools that helps the organization's leadership to manage specific activities in crisis situations and which helps to create conditions for the restoration of the pre-crisis state and it also help with overall coordination of crisis response of organization for avoiding or minimizing damage (Soušek et al. 2010). Individual concepts can be separated after recognizing errors that arise during individual management processes. Safety management error will arise in lower level of security, such as dealing with emergencies, failure to safety information and communication flows, failure of technology without substitution, etc. Uncontrolled or poorly managed risks will not prevent existing and future risks in the future. There will not be solution proposal to eliminate the effect of undesirable effects (Smejkal, Rais 2010). Errors on $\mathrm{BCM}$ may be described as faults in the process of packing a parachute. They are not recognizable until it's too late

These terms are also linked to certain resulting documents. Constraints and differences can then simply be represented on these materials (Figure 1.). The Activity Continuity Plan is linked to the basic reporting of emergencies, risk analysis and crisis management plans and emergency planning. It creates together a comprehensive process of recovery from unexpected events which threaten the stability of rail transport system.

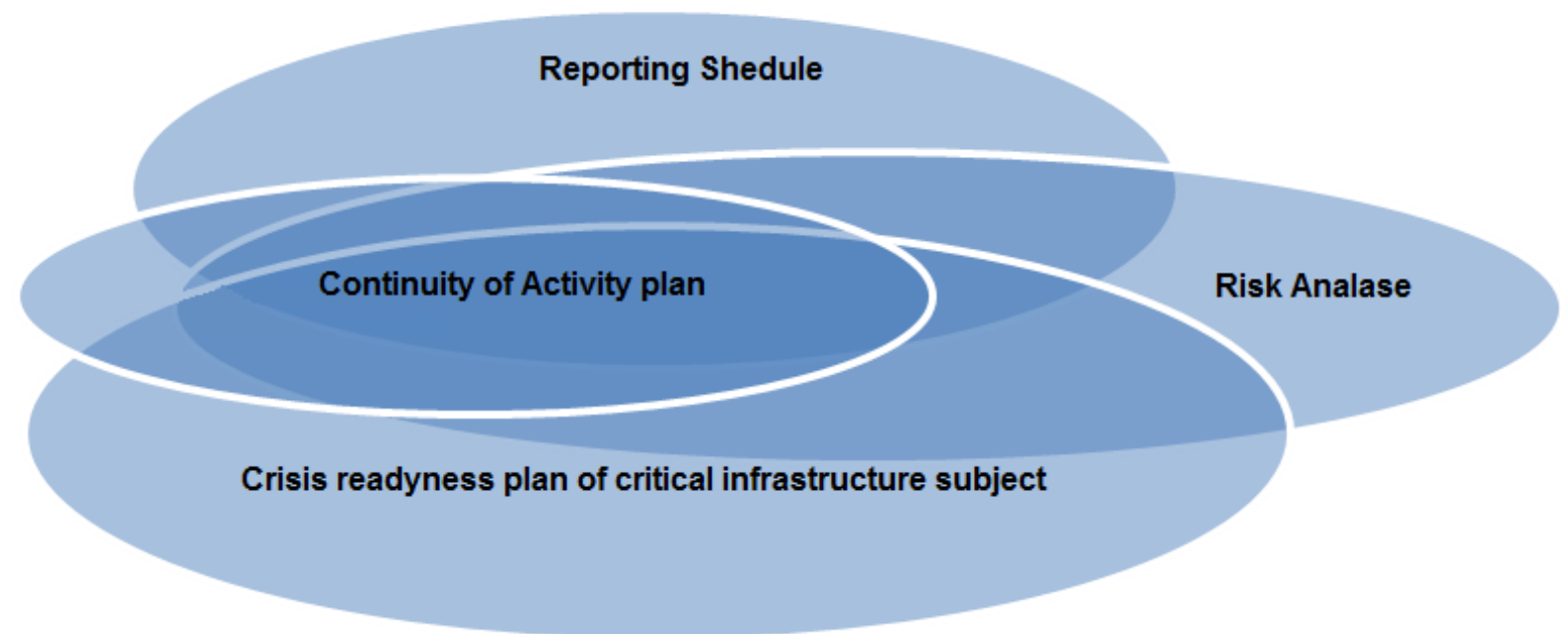

Fig. 1. Connectivity of documents related with crisis management, safety management, risk management and business continuity management Source: authors

\section{Business continuity management system in the Infrastructure managers and Train operating companies}

Like a first step is necessary start of the Business Continuity Management System (BCMS). One option is a systematic approach to the Business Continuity Management. The systematic approach is a one way to start the continuity management process. In this case, the Business Continuity Management is a set of organizational, personal, material, technical, financial and other measures to provide the necessary resources for the implementation and strengthening processes during extraordinary and crisis situations. The necessary step is that BCMS must be used in all fields in the transport company.

For creating BCMS are important 4 basic processes. The results from these processes are transformed outputs meeting the BCMS requirements and expectations from the surrounding area. It is PDCA (plan do check act). This process is well known like a Deming process, because it was used in 50's years in Japan. W. E. Deming taught Japans made their product in higher quality (Fuchs, Němec, Soušek, Szabo, Šustr, Viskup 2015).
At the start of the BCMS implementation, the person responsible for the Business Continuity Management organization should be identified in the subject. This person has the full responsibility for ensuring success of BCMS. In addition, it is necessary to identify a person or a team to implement and maintain the BCMS. These people may be from different parts of an organization. It depends on the size and organizational structure of company. If the structure of the organization requires it, it is possible to identify in each department the person or persons who will be assisting in the implementation of the Business Continuity Management. All responsibilities, powers and roles in the BCMS of all these designated persons should be listed in the duties descriptions and competency profiles (Soušek, Rozová, Němec, Šustr 2017). It is appropriate that these competencies and responsibilities are also subject to audits. The company should ensure that BCMS is embedded in the workers evaluation policy.

\section{Process Analysis}

For the BCMS is necessary holistic approach. Holistic mean, that process proceeds from the whole to the parts. First, the overall meaning is explored, and after 
overall meaning, individual details are explored. It should be noticed that all properties of a system cannot be determined or explained only by exploring parts of it. The "whole" (from the Greek holos) is important to this concept, and each part is usable with the other parts or with the whole system. Because the analysis is generally based on the decomposition of the whole on the elementary part, it is possible to analyse the core of the activity, i.e. the quantum of continuity of activities. The aim of the analysis is to identify the essential and necessary properties of the elementary parts of the whole, i.e. to know their nature and order.

After introduction of continuity politics must be must be fulfilled tasks by the managers. It is necessary for understanding actual processes in the railway company and understanding processes in individual company departments with regarding to the whole system. In addition an analysis of existing processes is required. The goal of the analysis is a deeper understanding of the processes and their parts (parts include activities, connections, outputs, the possible changes and the establishing to the new processes).

There are a lot of processes in the railways that fit each other. It crosses the various components of the organizational structure of the railway company as well as between the various railway transport system subjects. Processes have both influences external and internal. In each activity, inputs and sources are transformed into outputs. The business process can be represented using graphic symbols. The purpose is to define process inputs, sources, process itself, individual activities, goal and outputs associated with goal. Important feedback can be found in this step (ČSN ISO 22301, 2013). A simple tool for process orientation is a process map that should be a clear process schema (model).

The process model for analyse of processes performed on the Czech railway was created. The process model is composed the first and the second level of processes, created for the Infrastructure Manager. In most entities operating on the Czech railway, functional management is implemented with the logic of specialized departments (Rozová, Šustr, Soušek, Šohajek 2018). Each department is responsible for the activity which is performed by it.

The first-level model was designed to capture three basic process groups. Other processes are management and support. The main process is a key area which fulfilling the subject of business, and the main field of business. For the infrastructure manager, processes were included in this group:

- operationabilty of railways;

- organization and control of railway traffic;

- the national property management;

- development and modernization of the railway infrastructure.

Supporting processes for the Infrastructure Manager as support for the main processes are:

- information technologies;

- finance;

- health and safety in the work;

- fire protection;

- human resources;

- environmental contains.

Management processes create conditions for the proper functioning of other processes. They provide corporate governance and integrity, development, or business performance management. The Infrastructure manager management processes are:

- direct management activities

- methodical management activities;

- audit, documentation, precautionary measures.

In the Figure 2 is map of the Infrastructure manager processes in first level. 


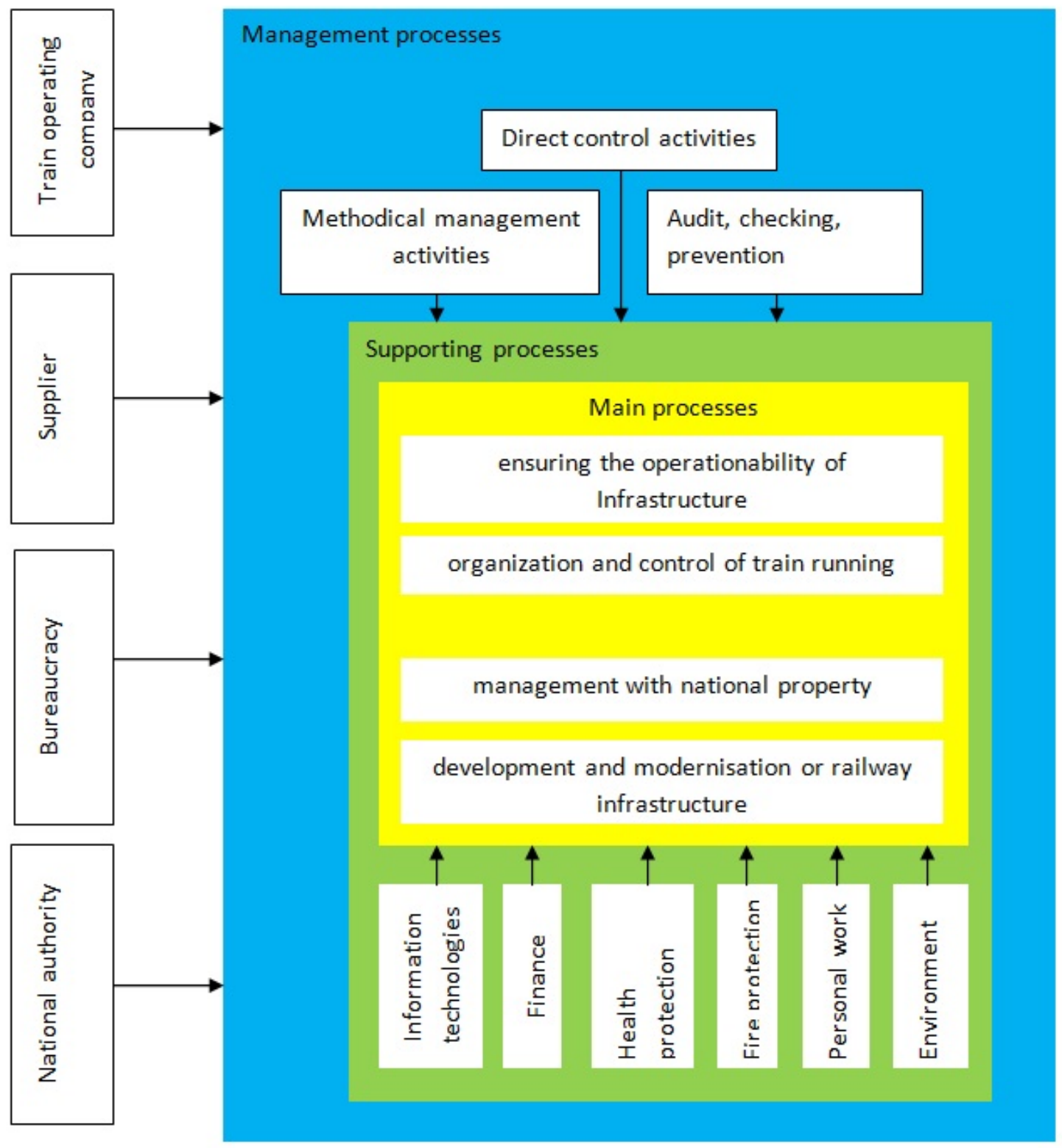

Fig. 2. Map of the Infrastructure manager processes on first level Source: Authors

The model of second level (Figure 3.) shows the processes at the Infrastructure manager executive units. 


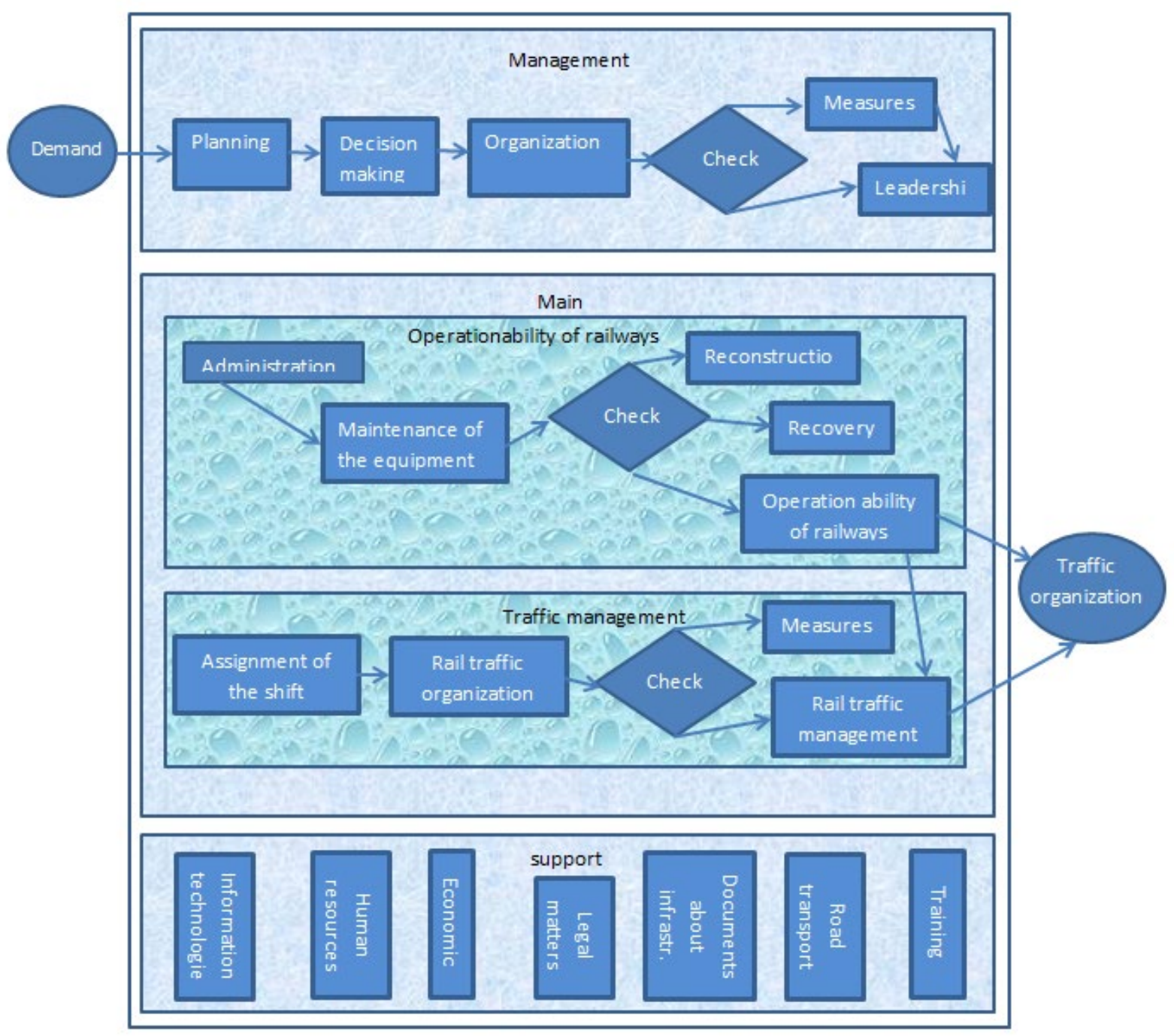

Fig. 3. Map of second level of Infrastructure manager processes Source: Authors

\section{Criteria for evaluation of Activities}

The choice of criteria relevant to the evaluation have affects the outcome. Individual activities can be evaluated according to the monitored parameters. Partial values can be used for the overall evaluation of the department, section or enterprise.

Creating a purposeful set of criteria for the continuity assessment of activities is an important step that can significantly influence the final results (Sharp 2009). The specified set of evaluation criteria should therefore meet certain requirements. The set of criteria should be such as to allow assessment of all significant long-term and shortterm both - positive and negative, direct and indirect impacts. Each criterion must be clearly and conclusively defined. Furthermore it must be also defined the way it is going to be measured. Each aspect should only come into the evaluation once, the criteria should not overlap. It is most important to choose the correct number of criteria (properties). Too many features can make it difficult or even impossible to find solutions. If there is too few of them, there is a risk of omitting some important aspects vital for valid evaluation. It is therefore essential to find a sufficient number of characteristics with sufficient information and discernment. The rationality of creating assessment criteria depends on the thorough knowledge of the assessed object, on the structural as well as functional system of understanding. 
The system analysis shows that the partial value of the continuity $h$ activity depends on the questions:

- how much it can be done in extraordinary event (e. g. crisis events);

- how long the activity being evaluated does not have to be carried out without the consequent problems;

- how many activities are interconnected with the disturbing activities;

- it is possible to replace the activity, if this activity can be performed by another worker or at another workplace;

- how much is required the specialization of resources for activity;

- there are effective measures, steps or practices addressing risk reduction.

To assess the continuity of activities, 6 basic criteria are proposed, which are relevant to the previous concerns. Table 1 lists the individual criteria for with their label.

Table 1. Criteria for evaluation of activities continuity

\begin{tabular}{|l|l|}
\hline Criterion name & label \\
\hline Fulfilment of Activity & $p$ \\
\hline Continuity of Activity & $k$ \\
\hline Interconnectivity of Activity & $v$ \\
\hline Reachability of Activity & $d$ \\
\hline Difficulty of Activity & $n$ \\
\hline Vulnerability of Activity & $z$ \\
\hline
\end{tabular}

Source: Authors

Fulfilment of an activity $\mathrm{p}$ is the parameter that evaluates the overall use of the activity in any situation, both in the normal state and in crisis situations. The value of the Fulfilment of an Activity $p$ can indicate that the activity is suitable only for a normal situation, a normal day-to-day regime without the possibility of its use in emergency situations or crisis situations. Under normal circumstances, all activities are valued equally because they meet the essential requirements for the outcome of the activity resulting from the expected benefit of performing the activity. In crisis situations, this standard expected performance requires more effort which is positively related to increasing intensity of the crisis. The value of this criterion of given activity is directly linked to individual crisis situations. For the actual evaluation of the value of the continuity of activities, a direct link to non-military crisis situations has been used.

The continuity of activity $\mathrm{k}$ is the very essence of continuity of activity, the basic observed parameter. It is assessed by the time lag between termination of the activity and the renewal of the performance without any subsequent problems.

The interconnectedness of the activity $\mathrm{v}$ indicates a number of previous and subsequent activities in general. For this evaluation, only a two-member causal chain was used in the sense of the cause (the activity under consideration) and the consequence (the amount of follow-up activities per activity evaluated).
The reachability of activity $\mathrm{d}$ is understood here as the representation of a worker who normally carries out the work by a worker from another, from another department, section, enterprise or outside the enterprise. In other words, it is about the substitution or substitutability for the worker who performs the activity and which, in the event of an emergency, would not be able to perform the activity himself. The term "reachability" was chosen from the point of view of its letter $\mathrm{d}$, because letters $\mathrm{z}$ and $\mathrm{n}$ are already used for following parameters. In the short term, the job performed by one worker can be divided among other workers who perform the same work in parallel workplaces. In the long-term absence, workers cannot be overloaded, as their fatigue would negatively influence their job performance. Therefore, it is also possible to consider the possibility of substitution of a worker who has been absent for a long time with a worker from a different workplace who would be able to perform the activity after a short period of training. In the partial evaluation of Reachability of Activity d, the required quality of representation can be expressed by the weight of the criterion, depending on whether a worker from the workplace is required (by increasing the weight of the criterion) or whether the worker can work from external sources (by reducing the weight of the criterion).

Criterion the Difficulty of activity $\mathrm{n}$ is characterized for this purpose as the number of workers involved for achieving this activity. If the number of people performing the activity is dropped consequently the performance is reduced and the desired result is not achieved. The value of this parameter can be extended by the financial cost, possibly space requirements for its implementation.

The Vulnerability parameter is $\mathrm{z}$ is reduced by rules, steps, or procedures. Measures to eliminate risks can only be partial or complex, depending on the degree of practice and their form.

The relationship between the criteria is also important for evaluation. It is also important to find the possible interdependencies or similarities between the various aspects of the assessment.

The basic concept for examining the relationship between two characters is their independence. The two criteria are independent if the assessment of the first one does not depend on the value achieved by the latter.

There is interconnection between Activity $p$ and the continuity of activity $\mathrm{k}$. It has its justification both in its normal state in terms of meeting its expected benefit and speed and the need for its use. It has its justification both in its normal state in terms of meeting its expected benefit and speed and the need for its use. If the activity is fulfilled even in crisis situations when the time demands for the activity are usually increased, then the period of possible interruption of the given activity should be one day at the most, in order to avoid the risk of delay. Therefore, if the p performance of the $\mathrm{p}$ activity is highly valued, there should not be too long interruptions, so the value of Continuity of activities $\mathrm{k}$ should be also high. Otherwise, there is a logical disproportion.

Indirectly there is also relation between the parameters of the activity Interconnectivity $\mathrm{v}$ the 
Fulfilment activity $\mathrm{p}$. The low value of the activity $\mathrm{p}$ leads to the assumption of the low connectivity to the surrounding activities, in other words, the greater the demand for performing the activity, the more other activities require such an activity and the more requirements for the results of given activity. It is not a direct link with any exceptions; however the general trend the connection is significant. Therefore, it can be generally assumed that the higher the value of the Fulfilment activity $\mathrm{p}$ higher the Interconnectivity activity v.

The Reachability activity $\mathrm{d}$ has a direct link to the Fulfilment Activity p; therefore, the activity $\mathrm{p}$ can be maintained in the long-term even in crisis situations. There is also another parameter for the need for the performance of the activity. If the activity is not sustained and continuously claimed, the activity is less necessary and for this reason it is not necessary to provide substitution.

There was no immediate link between the Fulfilment Activity $\mathrm{p}$ and the Difficulty Activity n. Both parameters are independent of each other. However, if the number of workers carrying out the activity in normal condition is reduced to a smaller number of workers in a crisis situation, the difficulty in performing the activity will consequently increase.

If the Vulnerability of activity $\mathrm{z}$ is defined like a resulting effect of the threat elimination procedures, is quite obvious that the performance of the activity $p$ is fully independent on it.

The continuity of activity $\mathrm{k}$ influences the relevance of activity $v$ and vice versa. An activity that has several previous and sequential activities is clearly more required and has a higher requirement for continuity of activities $\mathrm{k}$. The more people participate in the performance, the more difficult is to achieve the imperceptibility of such activity. Changes in the performance of the original activity can happen if the conditions change. The severity of activity $n$ is therefore indirectly dependent on Continuity of activity $\mathrm{k}$.

Indirect dependence is also between the Vulnerability of Activities $\mathrm{z}$ and the Continuity of Activities $\mathrm{k}$, because the more the risk is eliminated, the less the activity is interrupted. It is an indirect dependence.

The link between Achievements of Activity $d$ and Continuity of Activities $\mathrm{k}$ is quite obvious. The more the activity is substitutable, the less interruptible it becomes. There is a direct relationship here. On the other hand, no direct relationship has been found between the parameters of the Fulfilment activity $v$ and the Difficulty activity $n$, between Interconnectivity activity $\mathrm{V}$ and Reachability activity d, Interconnectivity activity $\mathrm{v}$ and the Vulnerability activity $z$. If the activity is limited or stopped as a result of the negative impact, then it will disturb or fully stop the follow-up activities, respectively, their number will be limited according to their priority.

The Difficulty activity $\mathrm{n}$ has no direct relation to the Reachability activity $d$. It is possible to replace the employees with the full required number; the difficulty of the activity must remain on the same level.
The vulnerability activity $\mathrm{z}$ does not have direct effect on the Difficulty activity $n$. In the case that the substitution is full within required scope, it will fulfil given activity and thus there is no direct link between the parameters of Reachability activity $d$ and the Vulnerability activity z. Table 2 shows the relationships between the criteria.

Table 1. Relation between criteria

Table 1. Relation between criteria
\begin{tabular}{|c|c|c|c|c|c|c|}
\hline & $p$ & $k$ & $v$ & $d$ & $n$ & $z$ \\
\hline$p$ & - & Direct & Direct & Direct & - & - \\
\hline$k$ & Direct & - & Direct & Direct & Indirect & Indirect \\
\hline$v$ & Direct & Direct & - & - & - & - \\
\hline$d$ & Direct & Direct & - & - & - & \\
\hline$n$ & - & Indirect & - & - & - & - \\
\hline$z$ & - & Indirect & - & & - & - \\
\hline
\end{tabular}

Source: Authors

\section{Conclusion}

Continuity is actually a process that is characterized by time, flow, and unity. The continuity of rail transport activities should ensure the ability of each individual participant to strategically and tactically plan, respond appropriately to extraordinary circumstances, maintain or resume operations.

The continuity of railway company activities is an activity that aims to minimize the recovery period so as to avoid the development of a crisis situation. The severities of a crisis situation usually increase exponentially, depending on the interruption time. The continuity of activities also helps solving possible critical situations that can disrupt the operation of the transport company.

The transport company BCMS with right calibration have optimal boundary. Thanks to the optimization of the BCMS is possible to ensure required continuity of individual activities and reduce the possibility of disrupting the transport service on the area.

Everything that helps live and survive in a competitive environment can be valuable to rail transport. Thanks to the new technologies and modern management methods, the rail transport market share in the transport branch can be higher and the competitive advantage of rail transport can be expected to be more significant. A competitive advantage is also the introduction the continuity management of activities into the railway environment.

\section{References}

ČSN ISO 22301. 2013 Ochrana společnosti - Systém managementu kontinuity podnikání - Požadavky. Praha: Úřad pro technickou normalizaci, metrologii a státní zkušebnictví, 2013. 40 p. Tř́íící znak 012306.

Fuchs, P., Němec, V., Soušek, R., Szabo, S., Šustr, M., Viskup, P. 2015 The Assessment of Critical Infrastructure in the Czech Republic. In: 19th International Scientific Conference on Transport Means: Transport Means Proceedings of the International Conference. Kaunas, 
Lithuania: Kaunas University of Technology, 2015 p. 418 - 426. ISSN: 1822-296X

Rozová, D. 2015 Hodnocení klíčových činností kontinuity za krizových situací. Pardubice, 2015. 92 p. Diploma Thesis. University of Pardubice, Jan Perner Transport Faculty.

Rozová, D., Šustr, M., Soušek, R., Šohajek, P. 2018 Crisis management in the railway transport and their additions. In. 22nd International Scientific on Conference Transport Means 2018 - Proceeding of the International Conference, Trakai, Lithuania, Kaunas University of Technology, 2018 p. 1043 - 1049. ISSN: 1822-296X

Sharp, J. 2009 Jak postupovat při řízení kontinuity činností: Naplnění požadavků BS 25999 = The route map to business continuity management. Praha: Risk Analysis Consultants, 2009. 117 p. ISBN 978-80-254-3992-0.

Smejkal, V., Rais, K. 2010 Řízení rizik ve firmách a jiných organizací. 3. vyd. Praha: GRADA, 2010. 360 s. ISBN 978-80-247-3051-6.

Soušek, R., et al. 2010 Doprava a krizový management. Pardubice: Institut Jana Pernera, 2010. 260 p. ISBN 98780-86530-64-2.

Soušek, R., Rozová, D., Němec, V., Sustr, M. 2017 Business continuity management system in the transport. In: $21 \mathrm{st}$ World Multi-Conference on Systemics, Cybernetics and Informatics (WMSCI 2017), Orlando, United States, 2017 p. 185-190. ISBN: 978-194176364-3

Valášek, J., Kovařík, F., et al. 2008 Krizové řízení při nevojenských krizových situacích. Modul C. Praha: MVgenerální ředitelství Hasičského záchranného sboru ČR, 2008. 159 p. ISBN 987-80-86640-93-8. 